Article

\title{
A Woman by Nature? Darren Aronofsky's mother! as American Ecofeminist Gothic
}

\author{
Alexandra Hauke \\ Department of American Studies/Cultural and Media Studies, University of Passau, 94032 Passau, Germany; \\ alexandra.hauke@uni-passau.de
}

Received: 2 April 2020; Accepted: 18 May 2020; Published: 26 May 2020

check for updates

\begin{abstract}
In this essay, I discuss Darren Aronofsky's 2017 feature film mother! in the context of an intersectional approach to ecofeminism and the American gothic genre. By exploring the histories of ecofeminism, the significances of the ecogothic, and the Puritan origins of American gothic fiction, I read the movie as a reiteration of both a global ecophobic and an American national narrative, whose biblical symbolism is rooted in the patriarchal logic of Christian theology, American history, female suffering, and environmental crisis. mother! emerges as an example of a distinctly American ecofeminist gothic through its focus on and subversion of the essentialist equation of women and nature as feminized others, by dipping into the archives of feminist literary criticism, and by raising ecocritical awareness of the dangers of climate change across socio-cultural and anthropocentric categories. Situating Aronofsky's film within traditions of American gothic and ecofeminist literatures from colonial times to the present moment, I show how mother! moves beyond a maternalist fantasy rooted in the past and towards a critique of the androcentric ideologies at the core of the 21st-century Anthropocene.
\end{abstract}

Keywords: ecofeminism; American gothic; ecogothic; feminist literary criticism; Christian theology; Anthropocene; (post)maternalism

Nature is a Haunted House - but Art—a House that tries to be haunted.

Emily Dickinson (1876)

\section{Introduction}

Darren Aronofsky's 2017 motion picture mother! is an allegorical retelling of the Book of Genesis with an arguably feminist twist on the patriarchal qualities of Christianity, U.S. American politics, and climate change. It has received extensive criticism post its initial cinematic release for the ways it allegedly "goes out of its way to artfully alienate or confuse audiences" through its "deranged [ ... ] depiction of a woman under increasingly heavy siege from within her own life"1 ${ }^{\prime \prime}$ Critics' discomfort in light of the film's complex negotiations of such controversial subjects as religion, women's rights, and environmental depletion in the context of a darkly gothic relationship drama speaks to the necessity of discussing mother! in relation to 21st-century hazards of ecological, economic, and socio-cultural crises. In this essay, I will read Aronofsky's most recent feature film across ecofeminism and the American gothic style. Thereby, I will carve out the ways in which mother! draws on notions from ecocriticism, feminist theory, and (eco)gothic studies to claim an intersectional space where women and motherhood can become more than naturized fantasies of past and present andro- and anthropocentric theologies. Through its additional allusion to American national narratives of discovery and conquest,

\footnotetext{
1 (Hughes 2017).
} 
a recurring theme of the American gothic invoked through images of frontier wilderness, the film situates its diegesis in an unambiguous political realm whence it critiques the alleged exceptionalism of U.S. American interests to remind viewers of their responsibilities in taking action against human and non-human injustice. An intersectional reading of mother! as an American ecofeminist gothic project ultimately allows the film to counteract its critical ascription as a "pretentious mess" ${ }^{2}$ and, instead, to live up to its artistic and political complexities in the face of the expanding horrors of the Anthropocene.

\section{Ecofeminism, Ecogothic, and American Ecopoetics}

In 1993, the essay collection Ecofeminism, by Vandana Shiva and Maria Mies, laid down the groundwork of almost three decades of political engagement and academic theorizations by scholars and activists in the emerging discipline of ecofeminism. In its early stages in the 1960s and 70s, this movement emerged from a growing number of protests against the connected notions of ecological destruction and female marginalization. Shiva and Mies republished Ecofeminism in 2014, observing in the updated foreword that the socio-political challenges of the early 1990s have only become more pressing and that "the rape of the Earth and the rape of women are [still] intimately linked-both metaphorically, in shaping world-views, and materially, in shaping women's everyday lives". ${ }^{3}$ From its origins, ecofeminist thought has critically engaged perspectives from fields that are now known as ecocriticism and gender studies, emphasizing that "the liberation of women cannot be achieved without the simultaneous liberation of nature from the clutches of exploitation". ${ }^{4}$ From this follows that both women and land in all its forms are dominated by the patriarchal logic of conquest, manifest, first and foremost, in gendered language that ascribes to women the feminized and naturized properties of 'Mother Nature' or 'Mother Earth'. Such perpetuations insinuate an exclusive, innate disposition of inferiority on behalf of women and nature, signaling that to conquer one is to conquer both at once.

In recent decades, critical engagements with these detrimental determinisms of feminine biology and ecology have led ecofeminists to offer more intersectional arguments. This has opened up a plurality of ecofeminisms that recognize the diverse concerns of all groups targeted by the white, male, heterosexual norm for their allegedly inherent femininity and different forms of 'otherness'. A major focus lies on queer feminism and feminism of color in this respect, whose projects and protests are even more violently co-opted by the neo-liberalist, capitalist, andro-, and anthropocentric demands of the 21st century than the more conventionally abstracted agendas of white feminists. It should not go unsaid, therefore, that the focus on the emancipation of all feminized others continues to steer ecofeminism in new directions in order to liberate them from domestic and public violence, segregation, and oppression. These means of aggression, which affect queer women and women of color by exponentially increasing rates, emerge as results of what Karen Warren terms the "isms of domination", i.e., naturism, sexism, racism, and classism, to which other ecofeminists have added, among others, ableism, ageism, essentialism, and colonialism ${ }^{5}$. Warren's intersectional understanding of ecofeminism is illustrated by the use of a quilt:

[N]othing that is knowingly, intentionally, or consciously naturist, sexist, racist, or classist [ ... ] belongs on the quilt. Nor does anything that is not, in some way, about nonhuman nature or human-nature relationships. An ecofeminist philosophical quilt will be made up of different 'patches,' constructed by quilters in particular social, historical, and material contexts. ${ }^{6}$

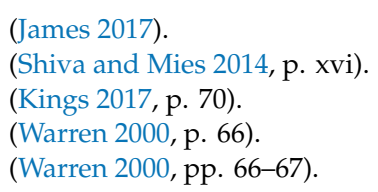


The quilt as a textual, semantic, and cultural symbol has been recognized across a variety of disciplines and echoed by ecofeminist scholars such as Greta Gaard, Mary Phillips, and A.E. Kings as well as, particularly, queer ecofeminists and ecofeminists of color such as Yvette Abrahams, Phyllis Young, Kishi Animashaun Ducre, Ambelin Kwaymullina, Catriona Sandilands, and Fatimah Kelleher. The latter especially vouch for the necessity to integrate queer spaces and ecologies as well as black and indigenous knowledge systems into debates about social, cultural, political, and ecological justice among and between all generations and species on the planet, now and in the future. Carol Gilligan and Joan Tronto, in turn, have contextualized such calls to action through the idea of an "ethic of care" for the world and all its inhabitants. In this context, care takes a decisive route to decolonize ways of imperialist thinking and acting by emphasizing the psychology of political affairs and thus the responsibility for the maintenance of human interaction, morality, decision making, and justice. ${ }^{7}$ Yvette Abrahams emphasizes in a treatise on black (eco)feminism the importance of care in the context of the earth's soils and self-care for women's bodies, an interconnection that must be honored by any project advocating the future sustainability of both planet and people. ${ }^{8}$ Mary Phillips adds to this idea a specifically "ecofeminist notion of embodied care" which must be "developed as a social and political as well as an individual practice necessary to bring about radical changes in our relationships in a more-than-human world". ${ }^{9}$ Such an ethics runs counter to the essentializing concerns of feminine ethics tied to women's allegedly natural(ized) features and bodily functions and emerges as a means to subvert "sets of interrelated and hierarchical dualisms, such as mind/body, reason/nature, reason/emotion, masculine/feminine or human/nature", ${ }^{10}$ which are at the center of patriarchal, anthropocentric, and colonialist ideologies. Phyllis Young stresses that indigenous women are especially vulnerable to these binary forms of domination, which often result in "displacement" or even "statelessness" 11 for the affected individuals due to a lack of care for their knowledge of their land and experiences on the part of Western authorities. An intersectional ecofeminist conception of care, as such, not only challenges the simultaneous disembodiment of diverse sets of women, the objectification of the female body, and the absence of female agency. It also undermines the essentialist idea of women as synonymous with nature because of the naturally given disposition of mothering and practices of maternalist care, wherein female corporeality is reduced to biological processes like menstruation, childbirth, and breastfeeding. These notions resonate with the earliest concerns of ecofeminism, namely to decenter, unthink, and reconfigure the interconnected disenfranchisement and commodification of women and nature, which is created and perpetuated by a patriarchal logic.

In the 21st century, the patches of the ecofeminist quilt thus continue to evolve into a mosaic of intersectional initiatives and theorizations. This multidimensional collection of ideas sports a focus on decolonizing Western ideals, which are rooted in androcentric understandings of man as superior "while women, nature and all else that do not conform are 'othered' to confirm and justify their subordination". ${ }^{12}$ Such a conceptualization lends itself especially well to the study of narrative forms that have shaped and continue at once to perpetuate and subvert such principles. As I will show in the following section, Darren Aronofsky's film mother! serves as a prime example of this two-way process of women's coercion, which is, at once, a common theme in feminist and gothic literary modes. The more the protagonist in mother! works to resist her subordinated status, the more her desperation grows; she is never allowed to break out of her prison because male dominance in the form of her husband-an allegory of God-and his/His faithful followers retain the upper hand. There is, thus, always the hope for mother's agency amidst the many instances of her subjugation but never the

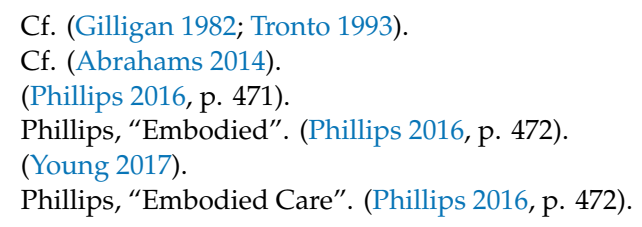


realization of her liberation. This form of representation, whereby the woman must settle for what little freedom she can get or perish, is reminiscent of such well-known literary and cinematic American texts as Charlotte Perkins Gilman's “The Yellow Wallpaper” (1892), Shirley Jackson's We Have Always Lived in the Castle (1962), and Robert Eggers's The VVitch: A New England Folk-Tale (2015). In these examples, and many others, varying degrees of resistant potential on part of the female protagonists illustrate that sacrifice, compromise, and acceptance of limitations are the only ways to guarantee survival or a certain amount of freedom of thought, speech, or action. Additionally, what connects the women in Gilman, Jackson, Eggers, and Aronofsky's stories is their alignment with different forms of nature, specifically the American wilderness. As such, because of Puritan beliefs and their patriarchal aftermaths, the women must or are not allowed to tend to certain natural environments (gardens, farms); they must complete chores that are seen as naturally female or include natural elements (cooking, cleaning); and they must fulfil roles that are naturally, biologically, and culturally reserved for women (mothers, housewives, caretakers). Any disobedience on their part is punished with social isolation, imprisonment, banishment, or death.

The way these texts all speak to the simultaneous permanence and attempted deconstruction of the patriarchal status quo reaches a climax in mother! because the eponymous protagonist must die despite the sacrifices she is willing to make on behalf of herself and her child. On top of that, at the end of the film, a new wife and mother takes her place, who must undergo the same torture in an endless loop. As such, the aforementioned technique of displacement is further enforced by replacement. In combination with the film's title as a placeholder for all mothers who will be part of this cycle, this alerts viewers to the essentialist idea that, in such a patriarchal order, women are defined by their social and corporeal functions without care for their individual needs or desires. Lastly, while all four of these texts foreground a number of universal problematics about the interlinked subordination of women and nature, they are also significantly born out of particular American traditions of history-, myth-, and policy-making. While Eggers's The VVitch, set in 1630s New England, shows the most straightforward connections to Puritan worldviews regarding the roles of women and their natural environments in nature and culture, Jackson's New England fable carries forward the Puritan frontier impulse between a civilized town and a pair of uncivilized sisters who are chastised for living in a mansion along the edges of a forest without the rule of a man. Gilman's seminal short story similarly thematizes borders - between man and woman, sickness and health, and, most prominently, between the colonial mansion with a slave-keeping history in which the protagonist is kept and the garden outside her window she cannot access. This image of mastery, inscribed in the yellow taint of the walls that seem to bear traces of innumerable women who have tried to escape the shackles of the house's national past, shows the most direct connection to Aronofsky's film. J. Samaine Lockwood argues that Gilman "critiques nineteenth-century American culture for having prohibited white women's entrée into the temporality of the progressive modern nation". ${ }^{13}$ Similarly, in mother!, the titular woman is not only bound by a master and the outlines of a mansion with yellow wall paint that deny her access to the outside world, both geographically and culturally, she also becomes stuck between the inhibiting rules of Christian universalism and the political peculiarities of American nationalism and historicism. I will delve deeper into these ideas in the following section; however, the mother's infinite replacement at the end of the film is only one allusion to the ways American women like Gilman's narrator emerge as victims "not having entered national historical time, as being trapped in the same colonial conditions as their early-American foremothers". ${ }^{14}$ As I will show, these conditions define the respective protagonists because of their alleged natural disposition to physical and psychological weakness as well as their innate closeness to the environment, be it naturally grown or artificially constructed.

13 (Lockwood 2012, p. 88).

14 Lockwood, "Revival". (Lockwood 2012, p. 91). 
From this follows that ecofeminist literary criticism has taken on the role of "unmasking the metaphorical, conceptual links between gender, race, class, and representations of nature in literature [as] an important part of forming a more viable environmental ethic" ${ }^{\prime 15}$ in all scholarly fields and societies. It does so by reading the aforementioned ideas of displacement and subordination at the hands of patriarchal epistemologies across the paradigms of ecocriticism and feminist literary criticism. Susan Griffin's challenging feminist manifesto Woman and Nature: The Roaring Inside Her (1978) has been at the forefront of these critical pursuits and serves as a palpable point of entry into my understandings and applications of these ideas in this essay. Simultaneously, a work of cutting-edge theory and prose poetry, Griffin's treatise carves out a space for signposting and critiquing "the seemingly implacable wave of assumptions that have dominated Western culture, unexamined ideas that alienate us from nature, and from the material world, including our own bodies", 16 instead of bringing us closer to each other and thereby to our surroundings and ourselves. Woman and Nature thus narrates estrangement-of humans and 'other' humans, of humans and non-humans, of humans and the non-human - through a simultaneous appeal to listen, observe, communicate, and revel in our senses of belonging beyond conceptual margins.

Griffin's narrative opens with a prologue that initially frames disembodied, naturized, and feminized others in a patriarchal separation of woman as earthly nature and man as divine God:

He says that woman speaks with nature. That she hears voices from under the earth. That wind blows in her ears and trees whisper to her. That the dead sing through her mouth and the cries of infants are clear to her. But for him this dialogue is over. He says he is not part of this world [ ... ]. He sets himself apart from woman and nature ${ }^{17}$.

Masculinist hegemony dictates thought, speech, and narration in these lines so that man can purposefully detach himself from woman and nature, who are, in turn, united by and in the thicket of the forest, where woman not only speaks with nature but also through nature. The specters of the deceased attempt to reclaim their voices by taking advantage of woman's connection with the earth; as such, man not only links the environment with the feminized other but also recognizes that nature enables woman to communicate with a dimension beyond the physical sphere that created his powers. Woman is hence at once established as a naturized figure rooted in the soils and elements of the earth and as a supernatural creature whose abilities exceed—or can never reach—those of man. As Patrick D. Murphy observes about this passage, "women and nature are interrelated and in that interrelation is to be discovered women's strengths and a way past patriarchy's destructive limitations". ${ }^{18}$ However, man's initiative to disassociate from woman and nature also dips into the divine imagination of being above humanity: "He says he is not part of this world". Therefore, he positions himself beyond-i.e., above- the realm of the other, in the heavenly spheres of godly greatness from where he silences the conversation between woman and nature in an assertion of unilateral male privilege.

Griffin's descriptions of howling winds, whispering trees, singing corpses, and crying children also evoke a series of images inherent to a genre in which "nature becomes constituted [ ... ] as a space of crisis which conceptually creates a point of contact with the ecological": ${ }^{19}$ the gothic. Conventionally abstracted as a literary mode of uncanny atmospheres, spectral terrors, sublime poetics, and-more often than not-oppressed wives, mothers, and daughters, gothic fiction, when read across the controversies of gender injustice and ecological depletion, opens up new possibilities for critical discussion that can serve a variety of crucial functions. On the one hand, according to Diana Wallace, it can "simultaneously reinsert [women] into history and symbolise their exclusion", ${ }^{20}$ and, on the other,

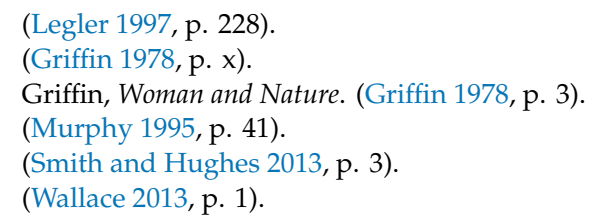


as Andrew Smith and William Hughes argue, it can "critique environmental destruction and advocate restoration" ${ }^{21}$ The role of wilderness as equivalent with nature has been a recurring theme in the American gothic style-in particular, ever since the first settlers imagined a social, cultural, and political frontier between two realms: the civilized old country, where the desire for knowledge, exploration, and domination of foreign realms and peoples reigned supreme, and the naturally wild New World, where indigenous communities, as America's primal and primary others, were branded as uncultured, beast-like animals with a ridiculed connection to their natural surroundings. Smith and Hughes observe in the introduction to their edited volume EcoGothic that the "landscape in the North American context seems to invite mastery through images of the frontier". ${ }^{22}$ The wood-adorned wilderness of the eastern shore of the U.S. nation-state provided ample space for colonizers to fulfil their Manifest Destiny, which "established an important imaginative symbolic structure that allowed them to 'read the world' to interpret signs from God", 23 and to exact violence against the innocent individuals they encountered there. This project was justified by the Puritan idea of chosenness as instructed by the highest divinity's ultimate wish for westward expansion and nationwide supremacy. Tom J. Hillard has called this culturally specific engagement with the New World wilderness "pre-Gothic symbolism", one which is "rooted deeply in Puritan theology"24 and "can still be located in many (if not most) subsequent Gothicized representations of nature". ${ }^{25}$ Thus, this settler-colonizer epistemology establishes, as Eric Savoy has also famously observed, the gothic as a quintessentially American genre whose literary and cinematic iterations dip into "the proximity of Otherness"26_represented by human and non-human others-as its principal trauma. In addition to the aforementioned literary and filmic examples, early American gothic texts such as Washington Irving's "The Legend of Sleepy Hollow" (1820), Nathaniel Hawthorne's "Young Goodman Browne" (1835), or Sarah Orne Jewett's "In Dark New England Days" (1901) also negotiate these frontier myths and Puritan anxieties of the New World wilderness, tracing clashes between the natural and the supernatural or between past traditions and the progressiveness of the New Woman. In these stories, which serve as reference points in and forerunners of the themes that frame mother!, elements of the American gothic and the ecogothic are interwoven with gender and body politics, bringing to the fore the ways in which women and nature have been subjected to processes of subordination ever since the early days of the United States. Particular attention is paid to the role of the forest as a liminal space between past and present, between uncanny terrors and sublime pastoral lifestyles, and between the woman as either a soft-spoken, passive victim or an unruly, disobedient broad with a penchant for evil.

The intersections between these othered categories have spawned important ecocritical readings of the American gothic, allowing scholars to recognize, for example, that "for the Puritans the New World does function as a sort of Gothic castle"27, one that is represented in the settlers' biblical narratives by the Garden of Eden as the holy paradise. In this setting, Original Sin triggered not only Adam and Eve's banishment but also the establishment of Eve-the woman-as the primary sinner, whose seductive propensities coerced Adam into betraying his faith and breaking his promise to God. Eden thus displays gothic qualities as the location of the world's "primal crime". ${ }^{28}$ It represents an early version of the haunted house at the core of U.S. national narratives that would become a fundamental setting in American gothic texts and thus a forerunner of the New World as a Gothic mansion, a point of intersection and inspiration for future fictional engagement with the alleged dangers of women and nature.

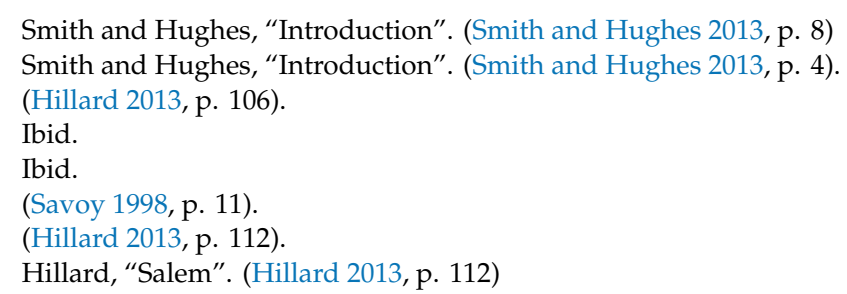


The ecogothic, through its junctures with wilderness gothic, frontier gothicism, ecophobia, and ecofeminism ${ }^{29}$, allows us to conceive of Griffin's Woman and Nature as a narrative of American ecopoetics. It invokes images of geographical, ecological, and gendered frontiers and provides allusions to the conjoined degradation of women and tribal peoples as inferior creatures close to nature who serve as valuable capital to dominant groups and are at the mercy of the aforementioned hierarchical dualisms set in place by Western epistemologies. Griffin thematizes this binary thought project throughout "Book One" of her manifesto before allowing what Murphy calls the "feminist counterchorus" to chime in and "emphasize the lesson already well established primarily by the 'Church Fathers,' that $\sin$ is a product of the earth, that women are closer to the earth, and that woman sinned first". ${ }^{30}$ Griffin's ecofeminist exposition ultimately runs parallel in its narrative strategies to both the Christian origin story of the world and the founding myth of America, which intersect at this point. The prologue begins with man's divine plan for woman and nature, very much like when God created the world in Genesis and when the settlers travailed vast oceans to seize now-American land from the 'savages' they encountered. Subsequently, in Griffin's opening, a "Navaho chant of the mountain that a grown man sits and smokes with bears ${ }^{\prime \prime 1}$ reminds man of the artificial separation of nature and culture, alluding to the settlers' mission to civilize indigenous peoples according to their European philosophies, while ignoring the holistic (meta)physical practices of pre-colonial native cultures. Next, man is confronted by an embodied female "countervoice" 32 pointing out that "[w]e are woman and nature. And he says he cannot hear us speak. But we hear". ${ }^{33}$ Feminist, environmental, and indigenous resistance to the male colonizer's aims to strip them of their agency thus brings Griffin's narrative to full (ecofeminist) gothic effect. Adam's and Eve's expulsion from Eden—attributed, as mentioned above, to the woman's Original Sin-and the settlers' confrontation with the original inhabitants of the New World emerge as the respective primary and ultimate gothic stories of the creation of humankind and the United States. In the extensive prefaces to her treatise, Griffin demonstrates awareness of and gratitude for the diversity of women from all over the globe who show continuous strength in decolonizing gender politics and environmental ethics to counter social injustices and cultural imaginaries. It is for this reason that the title Woman and Nature aptly uses 'woman' not only as a pointer toward female discrimination, but also as a marker that raises awareness of 'woman' as a universalized and artificial category in disenfranchising discourses that implies a collective problem without paying attention to the particular concerns of individual othered groups. The Navaho tribe mentioned above allows for one example of active indigenous agency in Woman and Nature; Griffin's tribute to Linda Hogan, Vandana Shiva, and Wangari Maathai, activists of color from Native North America, South Asia, and Africa, further highlights the significance of intersectional approaches to ecofeminism one study can pay homage to but simply cannot cover in their entirety. Similarly, 'nature' in the title, on the one hand, stands in more commonly for Mother Earth, the lands of the Earth, and the Garden of Eden, all of which receive special attention throughout Griffin's book. On the other hand, the term 'nature' delineates the supposed naturalness of all women in the context of biology, bodily propensities, and feminine care-giving, exposing once again an alleged universality and one-dimensionality of what it means to be a 'woman'. Lastly, in the context of the ecogothic, 'nature' speaks to the American wilderness at the frontier, segregating indigenous lands and peoples through settler-colonizer epistemologies and separating 'woman' (meaning both female individuals and the wide range of feminized others) from 'man' both physically-ecologically and politically.

Cf. Kevin Corstorphine's, Tom Hillard's, and Emily Carr's essays in EcoGothic (eds. Andrew Smith and William Hughes) explore these notions in the contexts of American gothic texts and authors, namely Ambrose Bierce's 1893 short story "The Damned Thing" (pp. 120-33), the 1999 feature film The Blair Witch Project (pp. 103-19), and Joy Williams's 1978 novel The Changeling (pp. 160-76) respectively. (Smith and Hughes 2013).

30 Murphy, Ecofeminist Critiques. (Murphy 1995, pp. 41-42).

31 Griffin, Woman and Nature. (Griffin 1978, p. 3).

32 Murphy, Ecofeminist Critiques. (Murphy 1995, p. 41).

33 Griffin, Woman and Nature. (Griffin 1978, p. 3). 
In this sense, as Hillard points out, the "primal crime central to the plots of early [American] Gothic fiction had a predecessor in the Puritan notion of [ ... ] Original Sin; and one marker of that sin was the fallen natural world-well before the first Gothic novelists transformed it into antiquated castles and monasteries". ${ }^{4}$ As I will show, Aronofsky's mother! allows a reading of gothic nature as both the divine Paradise and the wilderness at the American frontier, while simultaneously drawing a connection to current understandings of earthly ecologies and human exploitations thereof. The film narrates the eponymous mother's struggle for agency beyond her inherent biological function as a feminized and therefore naturized creature in an environment she is expected to care for but is not allowed to claim ownership of. An understanding of mother! as an American ecofeminist gothic text hence considers the dystopianism of otherness on part of the woman whose alleged sin is wanting what is rightfully hers-her body, her child, and her freedom to live. The film frames her struggle in the essentializing practices of past and present androcentric projects, whose gothicism arises from the oppressive logic of patriarchy. As such, while mother is allowed to approximate strategies of female self-representation through ideas of ecocriticism, feminist literary criticism, and (eco)gothic scholarship, she can never triumph over forms of hierarchy that dictate maternalism as the final and singular female safe haven.

In this context, it is not surprising that Griffin's Woman and Nature served as major inspiration ${ }^{35}$ for mother!. The title of Aronofsky's film, in connection with its original working label "Day 6", comments on its thematic interwovenness of biblical symbolism and maternal proclamation. On the surface, mother! is about a couple who struggles with their age difference, diverging visions of their future, and roles as man and woman, husband and wife, and poet and caretaker in overtly binary manners. Soon, however, the film develops into an exploration of the patriarchal logic at the core of Christian theology, American history, female suffering, and environmental crisis. This leads to an apocalyptic cry for help on part of the film's allegorical Mother Nature/Earth, portrayed by Jennifer Lawrence, whose efforts towards self-assertion are continuously undermined by God, played by Javier Bardem. Thus, an allegorical retelling of the Book of Genesis, Aronofsky's twelfth cinematic project dips into elements of home invasion horror as metaphor of settler-colonizer land seizure, allusions to American feminist gothic literature, and pertinent debates about climate change. In this manner, it highlights how the ecogothic as a set of ecological cautionary tales and the postmaternalist projects of much feminist work become representations of precarious anti-utopian realities in the poetics of an American ecofeminist gothic reading.

A critical examination of the limitations of human and natural creation, the impending ecological apocalypse as well as abuse, domestication, and body politics, the film ultimately echoes Griffin's assertion that "nature didn't really destroy herself, [ ... ] it was man who did it:" mother! thus "embodies what [Griffin] was saying in Woman and Nature in a very different and very vivid and powerful way"36. Griffin's manifesto dates back to the late 1970s, yet its dedication speaks to the ongoing relevance of the book's message in the contemporary moment: "These words are written for those of us / whose language is not heard, whose words / have been stolen or erased, those robbed / of language, who are called voiceless or / mute, even the earthworms, even the shell- / fish and the sponges, for those of us who / speak our own language". ${ }^{37}$ In the current Anthropocene, where human-on-human as well as human-on-nature violence are the most pervasive and interconnected forms of destruction, Griffin's words serve as a reminder that all feminized others, among them women, are still victimized, abused, and discriminated against. mother! has been received with harsh criticism where its feminist and environmental messages are concerned, yet Griffin herself maintains that " $[t]$ he

\footnotetext{
Hillard, “Salem". (Hillard 2013, p. 112).

(Kilkenny 2017).

Griffin qtd. in Kilkenny. (Kilkenny 2017).

Griffin, Woman and Nature. (Griffin 1978, p. v).
} 
inability of people to grasp this film is really related to their inability to grasp climate change. If we can make progress on both of them, that would be great" ${ }^{\prime 38}$.

I argue that reading Aronofsky's gothic project with a feminist-ecological awareness aids such an understanding of environmental disaster, while simultaneously highlighting the ongoing inferiorization of women through paternalistic thinking. mother! exposes the dominant gothic narrative of the woman as an "absent referent" 39 and of the mother as an "imprisoned or somehow abjected" 40 figure, pervasive ideas and representations that have existed since the emergence of the gothic genre. This highlights that "all Gothic women are threatened" 41 because they, in turn, pose a threat to those trying to eradicate them. Nature becomes a similar "type of blankness" in the American gothic mode, signifying "a crisis of representation" 42 and a cry for an environmental ethics of care that foregrounds climate change and the ways in which it affects diverse sets of disenfranchised communities. mother! emerges as a text that frames its eponymous protagonist in an exclamation of strategic maternalist creation to simultaneously emphasize and undermine her status as a victim of a feminine and anthropocentric ethics of care. Thereby, the film contributes to the complex debate around ecofeminist resistance movements and the ways these processes continue to be co-opted.

\section{3. mother!: An American Ecosystem}

When Aronofsky's mother! was first screened at the Toronto Film Festival in September 2017, critics and early viewers received prayer cards showing an adapted version of the Lord's Prayer, entitled "mother's prayer". Penned by American freelance writer and feminist Rebecca Solnit, the invocation reads:

our mother who art underfoot,

hallowed be thy names,

thy seasons come,

thy will be done,

within us as around us,

thank you for our daily bread, our water, our air,

and our lives and so much beauty;

lead us not into selfish craving and the destructions

that are the hungers of the glutted,

but deliver us from wanton consumption

of thy vast but finite bounty,

for thine is the only sphere of life we know,

and the power and the glory, forever and ever,

amen.4343(Thompson 2017).

Several reviewers have pointed towards the questionable intentions that inspired mother! as well as the use of "mother's prayer". They call Aronofsky's efforts "insufferable, overdetermined, pretentious and vain", ${ }^{44}$ reading his "nightmarish vision" as "intriguing" but "ultimately pointless". ${ }^{45}$ Additionally, some argue for the film's "simplicity" as the reason for that fact that the "action is so far out, detached from backstory or worldly implications, that the psychology of the protagonists is nearly effaced". ${ }^{46}$ Other critics, however, have spotted the value of the admittedly disturbing yet

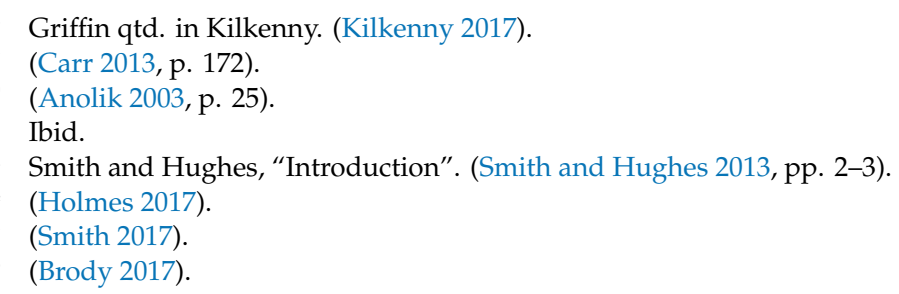


ultimately educational motion picture and Solnit's paratext. Caroline Hagood observes that "[w]hen it comes to what the movie's actually about, everyone has a theory: it's biblical, it's ecological, it's about fame, it's about what it's like to be the female love object of a male egomaniac a-hole, and much more" ${ }^{47}$ By acknowledging the abundance of reactions the film sparked since its premiere and by reading it across gothic literary criticism, Hagood testifies to mother!'s narrative complexity in terms of its generic, thematic, and critical potential. Solnit's "mother's prayer", its title's initials in lowercase to draw the connection to the film and counter the hegemonic practice of capitalizing nomers for underprivileged groups such as African or Native Americans, inverts the masculinist power of Christian writings and traces an arc to Griffin's employment of a feminist counter-narrative in response to male supremacist affirmations.

The mother's association in Solnit's poem with the seasons, bread, air, water, and beauty as well as environmental destruction, capitalistic consumption, and the finiteness of natural resources prepares the viewer for Jennifer Lawrence's personification of Mother Earth. The protagonist's sole purpose in mother! is to renovate the remote country house she and her husband, a poet named Him, recently purchased. She does this to encourage His creative efforts in order to overcome His writer's block-a metaphor for His immobilizing impotence-and eventually birth His first son. The film begins with the mother in flames and the house in ashes before He resurrects it with the help of an ominous crystal that will turn out to be the mother's heart. This artifact must be ripped from her body to keep the house-a representation of the generic gothic castle or haunted house as well as an allegory of Earth and the Garden of Eden-alive. The protagonist must thus make a sacrifice that traps mother, nature, and their eventual linked destruction in an infinite maternalist-essentialist circle. When mother paints the living room walls in a deep, earthly yellow, she hears a mysterious beating from inside the house's core. Her heart-the crystal as the centerpiece of the house-represents what Griffin calls "the roaring inside her" ${ }^{\prime \prime 8}$, its decreasing poundings signifying warnings as to the declining state of nature's health. As mentioned earlier, the walls also serve as a blunt allusion to the yellow symbolism in Charlotte Perkins Gilman's American gothic short story "The Yellow Wallpaper". Therein, the female protagonist descends into madness from post-partum depression as she is surrounded by the "repellent, almost revolting", and "smoldering unclean yellow" 49 walls she grows to hate more and more during her husband-enforced bedrest in a "colonial mansion, a hereditary estate, I would say a haunted house". 50 While Aronofsky's mother is not restricted to her chamber, she is nevertheless seemingly imprisoned in the house and as much under its spell as Gilman's narrator is under the "vicious influence" 51 of the wallpaper. Mother never goes further than the patio, separated from the surrounding forest and meadow by a conceptual frontier installed by God, confined to the house she comes to represent. Like Gilman's narrator, mother cannot access the nature outside the windows; she is limited to seeing them from a distance. As Lee Schweninger has observed, Gilman's story negotiates "the American woman's place in nature;" 52 additionally it highlights the American woman's (lack of) place in society. While Gilman's bed-ridden narrator gazes at an artificially constructed landscape in the form of "a garden in the late nineteenth-century in the United States", ${ }^{3}$ the protagonist in mother! longs for the naturally grown blades of grass that represent the American wilderness. These ideas are framed in Aronofsky's film through historical and contemporary American iconography in its visual aesthetics and U.S.-centric contextual mechanics in its political messages about discrimination, war, terrorism, and power-all of which are rooted in the American gothic's New World paradigm.

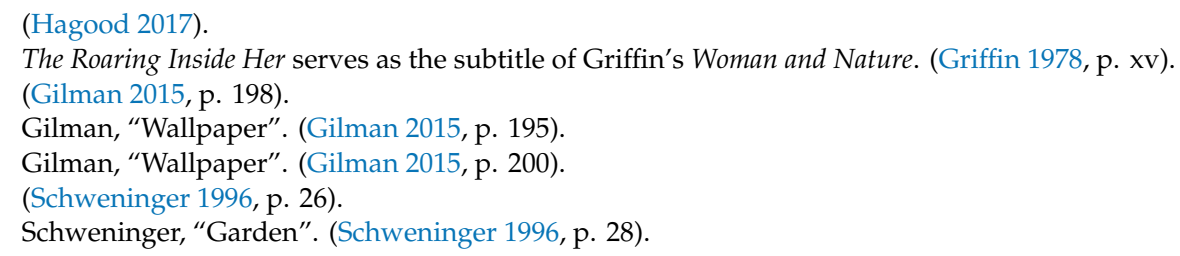


Mother's journey towards her inevitable doom begins when a strange couple arrives. Credited as Man and Woman, allegories of Adam and Eve, they are welcomed warmly and offered the guest room by Him while His wife remains suspicious of their intentions. Like Gilman's protagonist, who is taunted by her husband for her "imaginative power and habit of story-making", 54 mother is continuously discredited by her three housemates, who ridicule her for her childlessness, her unwillingness to drink alcohol, and her less-than-erotic underwear. Yet, the viewer still witnesses the biblical-ecological-female narrative through mother as a focalizer: her despair-ridden decline into a male-defined hysteria is thus enforced through an increasing visual blurriness of the screen's borders, which she can only alleviate temporarily by consuming an unidentified yellow powder. A number of critics have discussed the meanings and origins of the unidentified yellow substance without definitive answers; what is clear is that the drug has a calming, anti-anxiety effect on mother. It thus stands to reason that the film alludes to the United States' history of female hysteria, which the American Psychiatric Association accepted as a formal diagnosis until $1952 .{ }^{55}$ Treatment through drugs was only one of many attempts by the wider patriarchal culture to cure this supposedly chronic medical affliction, which was attributed primarily to women, in order to keep them from causing trouble and taking part in social life. While Gilman's narrator in "The Yellow Wallpaper", like the author herself, was prescribed the so-called rest cure for symptoms of depression by her doctor-husband, mother self-administers a temporary fix so as to retain her physical and cognitive abilities, hide her stress levels, and appear both sane and functional in front of her master. She is never allowed or never seems to crave rest, working tirelessly to keep any ensuing disagreements private so as to avoid public judgment of or outcry over her behavior.

While the claustrophobic point-of-view shots influence the psychological state of the viewer on behalf of mother's subjectivity, this exclusively female focus does not speak to her ultimate success or even survival. Rather, seeing through mother's eyes, the spectator experiences her pain firsthand. Thereby, the film narrates the common tale of gothic mothers, who, when "not actually dead are effaced by their husbands or other representatives of patriarchy in some way", whereby "immurement is a favorite method". ${ }^{56}$ As such, while Aronofsky's mother is not physically missing, like many maternal figures in the gothic, she can still be considered politically absent because "she troubles cultural categories and therefore must be expunged". ${ }^{57}$ When Woman blames mother for her sexless relationship with Him, the protagonist's shame turns to anger at her husband: "You talk about wanting kids but you can't even fuck me" ${ }^{58}$ Her accusation leads God to push her against a hallway wall in a violent attempt to call her bluff; while mother initially screams for Him to stop his rapist advances, she eventually surrenders in a tragically helpless way to a sex scene that is never fully depicted on screen but that will end in a pregnancy reminiscent of the Virgin Mary's immaculate conception. When mother announces the impending parenthood the next day, God is inspired to write again, proving that He Himself is His only muse. Male creation, regardless of mother's role in it, creates male creation. It will thereby result in the completion of God's most successful project: a continuously insinuated but unnamed poem that turns out to be mother!'s embedded foundation story of the world, the Genesis, which the film repeats in a self-reflexive manner in its frame narrative and hints at through Solnit's "mother's prayer" as its inversion.

Man and Woman, who, like mother, are nameless and thus reduced to their biological functionalities, at one point enter God's writing room to inspect and accidentally destroy the sacredly laid out heart-crystal. When they are asked to vacate the premises because of this betrayal, the Christian creation myth of Adam's and Eve's expulsion from Eden comes full circle in mother!. Before they can leave, their children, Younger and Older Brother, who emerge as representations of Adam's and Eve's

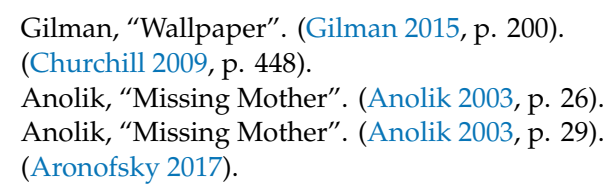


first two sons, Cain and Abel, arrive to trigger the film's version of the (ecological) apocalypse through its investment in the tropes of home invasion horror. When the film's Cain murders Abel, in line with the Bible narrative, the number of mourners who arrive to support the grieving parents escalates into an immense party of Godly followers. They take over the house in violent, self-evident ways that remind the viewer of colonial land seizure along the American frontier. Additionally, the film invests in this instance in the ongoing "debate surrounding overpopulation, which is often presented as the root of all environmental evil", when "two of the real culprits behind climate change" are clearly "overconsumption and corporate greed". ${ }^{59}$ This is illustrated in the film by the invaders' audacious heist of all material things, illicit intake of mother's food, and brutal demolishment of the house's interior-including mother's beloved kitchen sink, which, when broken, submerges the mansion in a cataclysmic outpouring of water suggestive of the Genesis flood myth.

Meanwhile, God's religious cult breaks into ceremonious chanting, dancing, and stomping while loud music, a rave party, and fist fights spin mother out of control. Her water breaks and she gives birth in His Edenic writing room upstairs (an allegory of heaven) while the American ${ }^{60}$ apocalypse-staged through unmistakable iconography in the form of military snipers, SWAT teams, and terrorist bombers-takes place in the living room downstairs (an emblem of earth). Mother Earth is thus forced to continue her corporeal labor while humankind maintains their exploitation of her nature, her home, her creation. To complete her misery, God's followers admire his poetic work so much-“They love it. They understand all of it. But it affects everyone in a different way. It is remarkable", He exclaims-that their worship of his newborn son will turn deadly. As they pass the baby around above their heads in a ceremonial ritual, his neck breaks before his body is ripped to pieces and consumed in a repulsive reminder of "Jesus the Bread of Life". ${ }^{61}$ It is at this point that the protagonist finally loses her reluctant self-control in an outburst of motherly accusation, disgust, and murder against the cult. This explosion is rooted in the "process of childbirth", whereby "the comforting integrity of the body is fragmented: one becomes two; what was internal and invisible becomes external and visible" ${ }^{62}$ Mother's deep-seated hostility towards humankind surfaces; she lashes out at members of her husband's following using a piece of shattered glass to stab and kill those in close proximity. Nature thus attempts to take revenge through the woman-and vice versa-in defense of her human and ecological ecosystems. Nevertheless, it is too late: the worshippers retaliate. They physically assault mother while calling her a fat pig, a cunt, a whore, and a tramp; they tear off her clothes, exposing her naked form in a discriminatory act of body shaming. They exact self-righteous mastery over her body in the name of the patriarch, reducing her to her genitals, equating her with an allegedly lowly animal, and framing her as an abominable sex worker: mother thus has no worth to them, not as woman, human, or keeper of the natural world. With no other way out, she uses the basement furnace-whose menacing flames are suggestive of the devil's hellish realm earlier in the film - to burn the house and its aggressors to the ground. Her first and only successful act of resistance in the film, mother's self-destructive agency, through the power of the natural element of fire, forces God to realize His efforts to create Paradise have been in vain. ${ }^{63}$ While mother is left a pile of ashes, He remains unharmed and mansplains mother's origin story:

mother: What are you?

Him: Me? I am I? You? You were home.

59 Kings, "Intersectionality". (Kings 2017, pp. 73-74).

60 In an ironic twist of the settler narrative, a Native American invader asserts "Proof we were here" as he tears down part of mother's house. Thereby, the film hints at a counterproductive revenge narrative on behalf of indigenous communities against the colonizers, which results, in the film, in the eventual annihilation of both sides of the frontier.

61 (John 6 2018).

62 Anolik, "Missing Mother". (Anolik 2003, p. 30).

63 This scene is especially reminiscent of Griffin's prologue outlined earlier, as God, like the man in Woman and Nature, must ultimately surrender His project-if only temporarily—due to woman's discovery of her power in nature. 
mother: Where are you taking me?

Him: The beginning. [ ... ] It won't hurt much longer.

mother: What hurts me the most is that I wasn't enough.

Him: It's not your fault. Nothing is ever enough. I couldn't create if it was. And I have to. That's what I do. That's what I am. Now I must try it all again. [ . . ] I need one last thing.

mother: I have nothing left to give.

Him: Your love. It's still there, isn't it?

mother: Go ahead. Take it. ${ }^{64}$

As God rips the heart that will crystalize into another mansion from mother's chest, the film's end reverts to the beginning (of the world) and thus comes full gothic circle: mother is restored in a new version of the house, recreated in a new body, and replaced by a new mother. She is caught in an endless loop of the "utopian idealism of [God's] project and its dystopian [ecological] aftermath". ${ }^{65}$ Nature's avenging efforts thus trigger not only a repetition of the divine patriarchal creation story of the world, whereby mother-as woman-is repositioned as the inferior feminized other. They also revive the American colonial narrative, whereby the religious cult members' initiative to take possession of the house metaphorizes the settler-colonizer attitude of land seizure: they vandalize the mansion's insides, steal any and all materials regardless of their value, and disregard mother as the home's caretaker by sweeping her out of the way through violent means. She has done nothing wrong throughout the entire film and has meticulously followed all rules, yet she is punished for her existence, her beauty, her gender, her inferiority, and, ultimately, her unwillingness to sacrifice her offspring - the only aspect in the world she feels truly connected to. The house, the land surrounding it, and everything she creates throughout the film were never really hers and so she becomes a victim of the religious following's divine mission to conquer, cultivate, and erase.

Paralleling the colonial project of Manifest Destiny, mother! reiterates the American gothic desire for "imaginative reconstruction of a historical event": 66 discovery, invasion, and domination of everyone and everything in the colonizers' way. Mother is thus overrun both in her role as a woman and as Mother Nature, for the house as a representative of the gothic castle, of the Garden of Eden, and of Planet Earth burns down and with it the protagonist. When both are revived by God in the end, the house returns to its former looks and state while the mother arises in a new body. As Griffin observes about this fact, "I think people don't understand that the Earth will regenerate at some point, but humans won't. We're destroying ourselves. [ ... ] We create destruction and then we just do it again, without learning from it" ${ }^{\prime \prime 6}$. This statement serves as the final testament to the American gothic's relationship with nature, defined by the impulse of repetition and the perpetual return of the repressed other. Be it the woman or wilderness, their interlinked subordination is the result of a deep-seated fear of both categories that emerged through the clash between Old World idealism and New World realism. mother!'s central narrative is thus one where ecofeminism and American nationalism intersect, where the oppression of various others as victims of frontier gothicism meets the exploitation of nature's land in a vicious circle of human supremacy, male hegemony, and ecocide. The film's power thus lies in its efforts to bring into conversation the terrors of climate change and androcentric ideologies within and beyond the woman-nature binary, while critiquing the lack of

\footnotetext{
64 mother!

65 Smith and Hughes, "Introduction". (Smith and Hughes 2013, p. 2).

66 Savoy, "Tenant". (Savoy 1998, p. 3).

67 Griffin, qtd. in Kilkenny. (Kilkenny 2017)
} 
understanding and self-conscious recognition of human complicity in these projects. Neither the ecological catastrophe nor matricide can be avoided or resisted in mother!, because both woman and nature must succumb to the American gothic imperative of settler-colonizer dominance.

\section{Conclusions: One Need Not Be A Woman to Be Haunted}

In an interview with Variety, Jennifer Lawrence, who was reading Charlotte Brontë's seminal novel Jane Eyre (1847) during the filming process of mother!, asserts that Aronofsky's project "is incredibly feminist in the way these Victorian, patriarchal novels show these loving, amazing husbands that are very slowly and delicately taking away their wives' dignity. [ ... ] To be a feminist movie, we don't have to all be women and all be aggressive. Before we knew what feminism was, people were writing these novels that showed women's strength being drained from them" ${ }^{68}$ My reading of mother! as well as its connections to other American gothic stories, such as Jackson's Castle, Eggers's The VVitch, and especially Gilman's "The Yellow Wallpaper", speak to this idea in the contemporary moment, which calls for ecofeminist discussions of apocalyptic scenarios for women and nature. The film posits mother as the angel of God's gothic house; she is shown no mercy by nature when the apocalypse strikes but is reinstated as maternal caretaker of her husband, castle, and earth, which proves the inherent falseness of the essentialist equation of woman and the natural world. This echoes Mary Phillips's thesis that a postmaternal ethics of care in the Anthropocene should "be reconfigured [ ... ] as a way of reconceptualising relationships that does not rely on 'feminine' maternal models but which stresses a 'feminist' [and thus intersectional] approach to connection, embodiment and emotion that is equally valued in both personal and political spheres". ${ }^{69}$ Aronofsky's mother figure cannot be created as the final girl of the film because she never had any agency, or a chance at ecofeminist democracy, in the first place. Still, she dips into earlier feminist literary initiatives, many of which echo colonial discourses about American women and wilderness, by raising ecocritical awareness across the intersections of socio-cultural categories (such as race, class, gender, sexuality, religion, dis/ability) and anthropocentric philosophies. mother! thus emerges as a cautionary tale of the apocalyptic consequences of the continuous and interconnected exploitation of women and nature and of the collective neglect of these repercussions for all humans.

Ruth Bienstock Anolik argues that "no woman is in greater peril in the world of the Gothic than is the mother;" after all, "the absent mother promotes the Gothic narrative". ${ }^{70}$ While the mother is physically present in Aronofsky's film, her allegorical status as Nature/Earth others her in a way that justifies God's patriarchal project, a mirror narrative of gothic colonialism, whereby the American wilderness is presented as an ambiguous space of frontier politics and postmaternal resistance campaigns. "[A]ll texts that restore the mother offer such resistance", Anolik continues; however, this restoration "posits a fantastic world in which the structures of patriarchy are reversed through the paradigms of maternal presence and paternal absence". ${ }^{71}$ Aronofsky reestablishes the mother as a nondescript, meaningless shell, as one in a long line of mothers subjected to constant erasure, because to let her win would deny the very real dogmas of 21st-century patriarchal epistemologies. It is this refusal to reproduce a maternalist fantasy that constitutes mother! as an iteration of the American ecofeminist gothic, aware of its dystopian colonial roots and working towards its responsibilities to all life forms.

\footnotetext{
68 (Setoodeh 2017).

Phillips, "Embodied Care". (Phillips 2016, p. 470).

Anolik, "Missing Mother". (Anolik 2003, pp. 25, 27).

Anolik, "Missing Mother". (Anolik 2003, p. 35).
} 
If nature is indeed a haunted house, as Emily Dickinson once postulated, ${ }^{72}$ then the gothic mother still awaits liberation from the androcentric prison that is the Anthropocene. Future ecofeminist poetics are thus compelled to look beyond the margins of feminine ethics: after all, we are women, and we are more than (our) nature.

Funding: This research received no external funding.

Conflicts of Interest: The author declares no conflict of interest.

\section{References}

Abrahams, Yvette. 2014. Moving forward to go back: Doing Black feminism in the time of climate change. Agenda 28: 45-52. [CrossRef]

Anolik, Ruth Bienstock. 2003. The Missing Mother: The Meanings of Maternal Absence in the Gothic Mode. Modern Language Studies 33: 24-43. [CrossRef]

Darren Aronofsky, director. 2017, Mother! Amazon Prime. Hollywood: Paramount Pictures.

Brody, Richard. 2017. Darren Aronofsky Says 'Mother!' Is About Climate Change, but He's Wrong. The New Yorker. September 20. Available online: https:/www.newyorker.com/culture/richard-brody/darren-aronofsky-saysmother-is-about-climate-change-but-hes-wrong (accessed on 3 December 2018).

Carr, Emily. 2013. The riddle was the angel in the house: Towards an American ecofeminist Gothic. In EcoGothic. Edited by Andrew Smith and William Hughes. Manchester: Manchester University Press, pp. 160-76.

Churchill, Lindsey. 2009. Hysteria. In Encyclopedia of Gender and Society. Edited by Jodi O'Brien. Thousand Oaks: SAGE, vol. 1, pp. 448-49.

Dickinson, Emily. 1986. Selected Letters. Edited by Thomas H. Johnson. Cambridge: Harvard University Press.

Dickinson, Emily. 2012. Selected Poems. New York: Dover.

Gilligan, Carol. 1982. In a Different Voice: Psychological Theory and Women's Development. Cambridge: Harvard University Press.

Gilman, Charlotte Perkins. 2015. Herland and The Yellow Wallpaper. London: Vintage Books.

Griffin, Susan. 1978. Woman and Nature: The Roaring Inside Her. Berkeley: Counterpoint.

Hagood, Caroline. 2017. The Gothic Literary Roots of Darren Aronofsky's Mother! Kenyon Review. September 29. Available online: https:/www.kenyonreview.org/2017/09/gothic-literary-roots-darren-aronofskys-mother/ (accessed on 2 December 2018).

Hillard, Tom J. 2013. From Salem witch to Blair Witch: The Puritan influence on American Gothic nature. In EcoGothic. Edited by Andrew Smith and William Hughes. Manchester: Manchester University Press, pp. 103-19.

Holmes, Linda. 2017. Mother! and the Cliffs of Audacity. NPR Pop Culture Happy Hour. September 15. Available online: https://www.npr.org/2017/09/15/551186730/mother-and-the-cliffs-of-audacity?t=1544212542999 (accessed on 4 December 2018).

Hughes, William. 2017. Mother! Earns a Rare, Semi-Coveted F from CinemaScore. AVClub. September 16. Available online: https://www.avclub.com/mother-earns-a-rare-semi-coveted-f-from-cinemascore-1818476876 (accessed on 20 October 2019).

John 6. 2018. BibleHub. Available online: https://biblehub.com/bsb/john/6.htm (accessed on 4 December 2018).

James, Caryn. 2017. Film Review: Mother! Is a 'Pretentious Mess'. BBC. September 14. Available online: http: //www.bbc.com/culture/story/20170914-film-review-mother-is-a-pretentious-mess (accessed on 19 October 2019).

Kilkenny, Katie. 2017. A Conversation with the Ecofeminist Who Helped Inspire 'Mother!'. Pacific Standard. September 20. Available online: https://psmag.com/social-justice/a-conversation-about-mother-with-susangriffin (accessed on 5 December 2018).

72 (Dickinson 1986, p. 225). The section title "One Need Not Be A Woman to Be Haunted" is also an allusion to Dickinson. It is an adapted version of the first line of her 1896 poem "Ghosts", in which she declares that "One need not be a chamber to be haunted,/One need not be a house;/The brain has corridors surpassing/Material place" (Dickinson 2012, p. 32). 
Kings, A. E. 2017. Intersectionality and the Changing Face of Ecofeminism. Ethics \& the Environment 22: 63-87. [CrossRef]

Legler, Gretchen T. 1997. Ecofeminist Literary Criticism. In Ecofeminism: Women, Culture, Nature. Edited by Karen J. Warren. Bloomington: Indiana University Press, pp. 227-38.

Lockwood, J. Samaine. 2012. Charlotte Perkins Gilman's Colonial Revival. Legacy: A Journal of American Women Writers 29: 86-114. [CrossRef]

Murphy, Patrick D. 1995. Literature, Nature, and Other: Ecofeminist Critiques. Albany: SUNY Press.

Phillips, Mary. 2016. Embodied Care and Planet Earth: Ecofeminism, Maternalism and Postmaternalism. Australian Feminist Studies 31: 468-85. [CrossRef]

Savoy, Eric. 1998. The Face of the Tenant: A Theory of American Gothic. In American Gothic: New Interventions in a National Narrative. Edited by Robert K. Martin and Eric Savoy. Iowa City: University of Iowa Press, pp. 3-19.

Schweninger, Lee. 1996. Reading the Garden in Gilman's 'The Yellow Wallpaper'. Interdisciplinary Studies in Literature and Environment 2: 25-44. [CrossRef]

Setoodeh, Ramin. 2017. Jennifer Lawrence on Why 'Mother!' Is a Feminist Movie. Variety. September 12. Available online: https://variety.com/2017/film/news/jennifer-lawrence-on-why-mother-is-a-feminist-movie1202555294/ (accessed on 7 December 2018).

Shiva, Vandana, and Maria Mies. 2014. Ecofeminism. London and New York: Zed Books.

Smith, Andrew, and William Hughes. 2013. Introduction: Defining the ecoGothic. In EcoGothic. Edited by Andrew Smith and William Hughes. Manchester: Manchester University Press, pp. 1-14.

Smith, Damon. 2017. Jennifer Lawrence Shines in Mother! but It's a Pretentious, Incoherent Film. The Irish News. September 13. Available online: https:/www.irishnews.com/arts/2017/09/13/news/jennifer-lawrence-shinesin-mother-but-it-s-a-pretentious-incoherent-film-1135033/ (accessed on 5 December 2018).

Thompson, Anne. 2017. 'mother!' Darren Aronofsky Answers All Your Burning Questions About the Film's Shocking Twists and Meanings. IndieWire. September 18. Available online: https://www.indiewire.com/2017/ 09/mother-darren-aronofsky-explains-mythology-allegory-bible-jennifer-lawrence-1201877848/ (accessed on 5 December 2018).

Tronto, Joan C. 1993. Moral Boundaries: A Political Argument for an Ethic of Care. New York: Routledge.

Wallace, Diana. 2013. Female Gothic Histories: Gender, History, and the Gothic. Cardiff: University of Wales Press.

Warren, Karen. 2000. Ecofeminist Philosophy: A Western Perspective on What It Is and Why It Matters. Lanham: Rowman and Littlefield.

Young, Phyllis. 2017. A Woman's Place in the Displacement: Ecofeminism, Indigenous Knowledge Systems, and Statelessness. CFFP. March 15. Available online: https://centreforfeministforeignpolicy.org/journal/2017/3/ 15/a-womans-place-in-the-displacement-ecofeminism-indigenous-knowledge-systems-and-statelessness (accessed on 15 May 2020). 